однорідного тіла i пружних параметрів з'єднаних матеріалів. Встановлено, що поява зони деструкції усуває концентрацію напружень у кутовій точці в широкому інтервалі параметрів з'єднання. Знайдено розкриття тріщини внаслідок утворення пластичних смуг i зони деструкції, яке може бути використано для визначення граничних навантажень.

\title{
Література:
}

1. Каминский А. А., Кипнис Л. А., Колмакова В. А. Расчет пластической зоны в конце трещины в рамках модели «трезубец». Прикладная механика. 1997. Т. 33, № 5. С. 70-76.

2. Каминский А. А., Кипнис Л. А., Дудик М. В. О начальном развитии зоны предразрушения вблизи конца трещины, выходящей на границу раздела различных сред. Прикладная механика. 2004. Т. 40, № 2. C. $74-81$.

3. Kaminsky A. A., Dudik M. V., Kipnis L. A. Initial kinking of an interface crack between two elastic media. Int. Appl. Mech. 2007. Vol. 43, No. 10. P. 1090-1099.

\section{DOI https://doi.org/10.30525/978-9934-26-043-8-16}

\section{ВПЛИВ ХВИЛЬОВИХ ПОЛІВ НА ОБ'ЄКТИ ЗАХИСТУ ТА ОСОБОВИЙ СКЛАД В УМОВАХ БОЙОВИХ ДІЙ}

\author{
Черненко А. Д. \\ кандидат військових наук, \\ начальник науково-дослідного відділу \\ наукового ицентру сухопутних військ \\ Національна академія сухопутних військ \\ імені гетьмана Петра Сагайдачного \\ м. Львів, Україна
}

Акустичні (звукові) хвилі i можливість їх використання у військових цілях віддавна були предметом розгляду військових дослідників та розробників озброєння і військової техніки. Такі хвилі, особливо інфразвукового діапазону, здатні паралізувати живу силу противника на великій території, а в окремих випадках можуть 
призвести до смертельних наслідків. Механічні хвилі, поширюючись у землі чи повітрі, взаємодіють 3 неоднорідностями середовища. Ці неоднорідності можуть бути природні або створені людиною - наземні та підземні інженерні конструкції, особливо оборонного характеру, житлові будинки, фабрики, заводи, культурні центри, метро, бомбосховища, бліндажі тощо [1, с. 15,2 , с. 166,3 , с. 40, 4]. Взаємодіючи 3 ними хвилі відбиваються, проходять всередину, розсіюються, створюючи певну силову дію на будови та людей всередині.

Розглянемо поширення пружної гармонічної нормальної хвилі у плоско-паралельному хвилеводі, поверхні якого паралельні площині $X Z$ i перпендикулярні осі $O Z$. Хвильовий процес не залежить від координати $y$. Для простоти вважатимемо шар, в якому поширюється хвиля, нев'язкою рідиною, а стінки хвилеводу - жорсткими. У цьому випадку усі функція (тиск, швидкість), які описують хвильовий процес, залежатимуть лише від часу $t$ та координат $x$ та $z$, тобто.

$$
p(x, z, t)=p(x, z) \exp (-i \omega t) .
$$

Функція $p(x, z)$ має задовольняти рівняння Гельмгольца [5, с. 122]

$$
\frac{\partial^{2} p}{\partial x^{2}}+\frac{\partial^{2} p}{\partial z^{2}}+k^{2} p=0
$$

та умові рівності нулю нормальних до поверхонь складових швидкості рідини на цих поверхнях

$$
v_{z}=0 \text { при } z=0 \text { та } z=h,
$$

або

$$
\frac{\partial p(x, 0)}{\partial z}=0, \frac{\partial p(x, h)}{\partial z}=0,
$$

де $h$ - товщина шару; $k=\omega / c-$ хвильове число; $\omega$ - частота коливань частинок середовища в процесі поширення хвилі; $c$ - поздовжня швидкість поширення хвилі.

Розв'язок крайової задачі (2), (3), поданий формулою (1), використовуючи метод розділення змінних [5, с. 169], для біжучої хвилі можна записати у вигляді

$$
p(x, z, t)=X(x) Z(z) \exp (-i \omega t),
$$


де $X(x)=\exp \left(i \gamma_{n} x\right), Z(z)=B_{n} \cos \left(\frac{n \pi}{h} z\right), \gamma_{n}=\sqrt{k^{2}-\left(\frac{n \pi}{h}\right)^{2}},(n=0,1,2,3 \ldots)$. Вираз для $\gamma_{n}$ отриманий з умов (3) на граничних поверхнях шару.

Розглянемо властивості нормальних хвиль. Вираз (4) описує хвилю, яка поширюється в напрямку осі $O x$ з хвильовим числом $\gamma_{n}$, при цьому амплітуда тиску змінюється вздовж фронту хвилі за законом косинуса. Множник $B_{n}$, який також характеризує амплітуду хвилі, визначається не граничними умовами на межах хвилеводу, а властивостями джерела звуку. Якщо ввести позначення $\omega_{k p n}=\frac{n \pi c}{h}$, то хвильове число моди набуває вигляду

$$
\gamma_{n}=k \sqrt{1-\frac{\omega_{k p n}^{2}}{\omega^{2}}}, \quad k=\frac{\omega}{c}
$$

де $\omega_{k p n}-$ називають критичною частотою $n$-ї гармоніки нормальної хвилі. Тоді фазову швидкість нормальної хвилі на основі (5) можна подати так:

$$
v_{n}=\frac{\omega}{\gamma_{n}}=\frac{c}{\sqrt{1-\frac{\omega_{k p n}^{2}}{\omega^{2}}}} .
$$

Кількість біжучих хвиль визначається 3 умови $n \leq N$, де $N$ знаходимо з умови рівності частоти критичній частоті $\omega=\omega_{k p n}$ або $\omega=N \pi c / h$ (залежності (5), (6)). Звідси випливає, що кількість нормальних хвиль $N$ дорівнює $N=\left[\frac{\omega h}{\pi c}\right]=\left[\frac{k h}{\pi}\right]=\left[\frac{2 h}{\lambda}\right], \quad k=\frac{\omega}{c}=\frac{2 \pi}{\lambda}$; квадратні дужки тут позначають цілу частину числа.

Середня за період коливань густина енергії на одиницю довжини хвилеводу для $n$-ої моди визначається за формулою $E_{n}=\frac{h \delta_{n}}{2 \rho c^{2}}\left|B_{n}\right|^{2}$, a середня густина потоку енергіï - виразом $I_{n}=\frac{\left|B_{n}\right|^{2}}{2 \rho c^{2}} v_{g n}, \quad$ де $\delta_{0}=1, \quad \delta_{n}=0,5(n>0)$, a $v_{g n}=c \sqrt{1-\frac{\omega_{k p n}^{2}}{\omega^{2}}}-$ групова швидкість $n$-ої моди. 
Аналіз отриманих залежностей (5), (6) вказує на те, що на великих віддалях від джерела амплітуди нормальних хвиль обернено пропорційні кореню квадратному 3 віддалі, густина потоку енергії нормальних хвиль обернено пропорційна віддалі. Слід відзначити також, що у твердих хвилеводах у зв'язку з наявністю поздовжніх i поперечних хвиль хвильова картина буде значно складніша.

Реальні джерела хвиль займають скінченну просторову область. Хвильові пучки, поширення яких близьке до поширення плоскої хвилі, для інфразвукових частот створити складно, хоч і можливо. Тому доцільно мати оцінку потужності локального джерела хвиль для досягнення на потрібній віддалі потрібної інтенсивності хвиль, при цьому орієнтування було на встановлену інтенсивність $I \approx 32,5 \mathrm{BT} / \mathrm{m}^{2}$, яка $\epsilon$ нижньомежовою для ефективної (з точки зору нанесення руйнації) дії на захисну систему.

Допустимий рівень коливань за санітарно-гігієнічними умовами визначається характером та інтенсивністю впливу на людей. За характером впливу на людей вібрація може бути загальною, що діє на людину через поверхні опор, і локальною, що передається через руки людини. Гігієнічну оцінку вібрації, що діє на людину, проводять згідно 3 Державними санітарними нормами України ДСН 3.3.6039-99. Показниками коливань $є$ середньоквадратичні або амплітудні значення віброприскорення, віброшвидкості й вібропереміщення. Замість цих трьох параметрів часто використовують логарифмічну децибельну шкалу, що служить певним синтезуючим умовним показником.

Отже в доповіді розглянуто особливості поширення хвиль у плоскому хвилеводі, зокрема при збуренні точковим джерелом, а також поведінку хвиль на межі контакту середовищ - відбиванняпроходження та розсіяння хвиль, силові характеристики дії хвиль. Приведено основи розрахунку силової дії пружних хвиль на інженерні конструкції за гармонійного та імпульсного збурень. На цій основі проведено кількісне оцінювання необхідної енергетики хвильового процесу для успішної силової дії на інженерні конструкції та людей. 3 дослідження випливає, зокрема, що використання природних хвилеводів має свої енергетичні переваги при хвильовій дії на споруди і людей і при відповідному опрацюванні може знайти своє місце у військовій практиці. Вивчено проблемні питання оцінки впливу інфразвуку на здоров'я людини. Висвітлено деякі особливості застосування ультразвуку в різних галузях, включаючи медицину, пов'язані з їх властивістю поширення в середовищі. 


\section{Література:}

1. Уайт Дж. Э. Возбуждение и распространение сейсмических волн. М.: Недра, 1986. 261 с.

2. Juergen A. Acoustic Weapons - A Prospective Assessment. Science and Global Security. 2002. Vol. 9. P. 165-234.

3. Захаров В.М. Зброя на нових фізичних принципах та способи їі застосування. Честь і закон. 2008. № 2. С. 40-55.

4. https://uk.wikipedia.org/wiki/Медична_акустика

5. Арсенин В. Я. Методы математической физики и специальные функции. М.: Главная редакциия физико-математической литературы изд-ва «Наука», 1974. $432 \mathrm{c}$. 